\title{
AN EXAMINATION OF THE IMPORTANCE OF PRE-ABORTION COUNSELLING
}

\section{Herman Strydom, Susan Humpel}

\section{INTRODUCTION}

Every woman, regardless of age, race or background with an unwanted pregnancy who considers abortion as an option has a need for objective and professional counselling. Legislation provides for pre-abortion counselling for the pregnant woman who requests abortion (Howes \& Green, 1997:18; Taylor, 1997:vi). The literature confirms the importance of pre-abortion counselling for the pregnant woman who considers abortion as an option (Howes \& Green, 1997:18; McCulloch, 1996:67). It also indicates that pre-abortion counselling corresponds with crisis intervention and calls for skills and expertise in the counsellor (McCulloch, 1996:67; Schlossberg \& Achtemeier, 1995:110; Sekudu, 2001:94; Van der Berg, 1997:78). Crisis intervention as a model for pre-abortion counselling is presented in this article, accompanied by relevant contextual aspects and am emphasis on the importance of preabortion counselling. Finally, the findings of the empirical investigation are also discussed.

\section{PROBLEM STATEMENT}

Some women are of the opinion that, if they wish to terminate their pregnancy, this can be done as a matter of course. However, the practical execution entails procedures that need to be adhered to, such as medical tests, sonar, appointments and counselling by professional personnel (Mkhize, 2000:96). Dondashe (2001:3) regards pre-abortion counselling as a prerequisite that has to precede abortion so that the pregnant woman can be afforded the opportunity to obtain sufficient information with a view to make a well-informed decision. Women occasionally experience counselling as a stumbling block in their way to having an abortion (Taylor, 1997:29).

Legislation determines the following: "The State must promote the provision of noncompulsory and non-prescriptive counselling before and after the termination of a pregnancy" (SA, 1996:1304). By providing the counselling, legislation therefore guides the woman who feels that she cannot proceed with her pregnancy (Mkhize, 2000:96). The permission aspect forms part of pre-abortion counselling. Legislation determines that only the permission of the pregnant woman is necessary for the termination of pregnancy. This implies:

- that a pregnant minor only needs her own permission for an abortion. Legislation determines that the pregnant minor must be advised to consult her parents, guardian, family members or friends prior to having the pregnancy terminated, but the abortion may not be refused if the minor prefers not to consult someone;

- and that the married pregnant woman can undergo the abortion without the permission of her husband (Britz, 1997:2; SA, 1996:1306).

According to Britz (1997:3), two newspapers reported in April and May 1997 that, after legitimisation of abortion, guidance for women who had requested abortion was not available. Although legally determined, counselling does not always take place, because of insufficient funds and personnel shortages at some of these facilities. Hence women who request an abortion can be exposed to the trauma of the abortion procedure with far-reaching effects on their lives, seeing that they were not given the opportunity to make an informed and wellconsidered decision. 
The pregnant woman who requests an abortion is dependent on social work aid. Crisis intervention is the obvious model to apply to deal with the unwanted pregnancy and envisaged abortion, seeing that it is a problem-solving process through which ego-supporting techniques are used to help the woman to normalise her functioning. Adequate counselling must be available to all pregnant women, which means that it must be of an outstanding quality and be conducted by professional social workers.

\section{AIMS AND OBJECTIVES}

The core of this article is to examine the importance of pre-abortion counselling and to discuss its contextual facets, based on crisis intervention as a model. The objectives are as follows:

- To discuss the nature, essence and purpose of pre-abortion counselling;

- To focus on crisis intervention as a model for pre-abortion counselling;

- To present the findings of the investigation into the importance of pre-abortion counselling.

\section{RESEARCH METHODOLOGY}

\section{Design and procedure}

The objective of this research is explorative and intends to gain insight into a situation, phenomenon, community or individual (De Vos, Strydom, Fouché \& Delport, 2005:106). Descriptive research has a systematic, objective and complete description of reality in mind (Strydom, 1999:78). The study thus entails a combination of explorative and descriptive objectives. By means of the survey procedure quantitative data were gathered to obtain information on people regarding a phenomenon of which they have knowledge (De Vos et al., 2005:166-167). A quantitative investigation focuses on variables and the data are statistically processed with a view to reliability. On the other hand, qualitative investigation focuses on the intrinsic meaning of human experience, which is not the aim of this study (Creswell, 2003:18; Rubin \& Babbie, 2001:209, 216; Strydom, 1999:74). The single system design was used as it enables study of a subject on a repetitive basis. It entails the planned comparison of observations in a pre-intervention period (base-line phase) with observations of the intervention period or even with the observation of a post-intervention phase (Bloom, Fischer \& Orme, 1999:321-357; De Vos et al., 2005:145; Royse, 2004:81-82; Rubin \& Babbie, 2001:327-329; Strydom, 1999:90).

\section{Respondents}

From January to March 200325 pregnant women who had requested an abortion and reported for pre-abortion counselling at Potchefstroom Hospital were involved in a pre-investigation. A maximum gestation period of 12 weeks was the only limitation. Following the preinvestigation, the population for the main investigation was identified and a sample was not used (Creswell, 2003:156).

All these respondents were pregnant women who were referred to Potchefstroom Hospital and who had requested to undergo an abortion, regardless of the period of gestation. Following a medical check-up by the gynaecology department at Potchefstroom Hospital, the patients were referred to the social worker (investigator) with pre-abortion counselling in mind. This group of pregnant women had not yet reached a gestation period of 12 weeks and had reported for preabortion counselling. By the end of ten months (in other words from the beginning of April 2003 to the end of January 2004), 150 pregnant women who had requested termination of pregnancy were involved in the main investigation. The investigator observed, gave thorough 
attention to the respondents, listened actively, and used her senses such as seeing, hearing, feeling and touching. In so doing, the investigator could absorb all possible information. Preabortion counselling was conducted in the office of the investigator and attention was given to creating a peaceful atmosphere for the respondents (Neuman, 2003:380,381). The pregnant women who had requested an abortion filled in self-designed questionnaires at the beginning and conclusion of pre-abortion counselling sessions. If a participant was not capable of filling in the questionnaire herself because of illiteracy, lack of understanding or emotional status, the investigator used this questionnaire as an interview schedule and filled it in on behalf of the participant (Rubin \& Babbie, 2001:210).

\section{Measuring instruments}

Self-designed questionnaires containing a variety of types of questions to determine the importance of pre-abortion counselling were filled in at the beginning and conclusion of preabortion counselling sessions (Royse, 2004:186,188; Strydom, 1999:116). The self-designed structured questionnaire consists of open-ended and closed questions, and the content is based on the existing pre-abortion counselling programme. Data obtained from the closed questions were computer processed by Statistical Consultation Services on the Potchefstroom Campus of North-West University. Data obtained from the open-ended questions were categorised and hand processed by the investigator. Thus the relationship between variables could be determined (De Vos et al., 2005:148-149).

\section{Ethical aspects}

Professional ethics with regard to the rights of the participant and the responsibilities of the investigator applied (De Vos et al., 2005:56). Attention was given to the vulnerability of the woman with an unwanted pregnancy and to how she should be treated in order to reach a positive outcome and to prevent any form of misleading confusion. Simultaneously, it was ensured that an accurate version of the situation was obtained by the investigator (Babbie, 2004:64-66; Creswell, 2003:64-65; De Vos et al., 2005:59). The following ethical aspects received attention in this investigation.

Permission was obtained from the Ethics Committee, Potchefstroom Hospital, and the departmental research committee, Health Department, North-West Province to undertake this research.

The Ethics Committee, Potchefstroom campus of the North-West University, approved the request to undertake this research project.

The questionnaires were compiled in Afrikaans and English and tested for equivalence in order to ensure the correctness of the translation.

This study does not demand high educational levels from respondents, because the same questionnaire was used as the interview schedule in cases where the respondent was illiterate or experienced a problem with the language. A volunteer interpreter was also used on several occasions.

The questionnaire was filled in anonymously and the investigator was present at the commencement of the individual interviews during which the questionnaires were filled in. Hence, the information was obtained directly from the respondents.

Interviews were arranged in advance and, in order to ensure confidentiality, they were conducted in the privacy of the investigator's office. 
Having explained the aim of the investigation, every participant was called upon to give her voluntary cooperation. The ethical implications with regard to the application of the results were worked through with the respondents, namely that results will be applied in the interest of other women experiencing the same crisis and that the quality of the social work service delivery with regard to pre-abortion counselling will be improved by it.

\section{DEFINITION OF CONCEPTS}

Counselling is a "process of help located firmly within the personal relationship between counsellor and the person in need" (Hildebrand, 1977:7). It is professional guidance to help a person cope with emotional and other personal problems in that the counsellor uses techniques such as advice, discussion, administration and interpretation (Dondashe, 2001:3). Counselling in the context of this study can be regarded as assisting the pregnant woman to make an informed decision about her unwanted pregnancy and it normally lasts at least three sessions, making it crisis intervention.

Pre-abortion is the period that lasts from the moment the pregnancy is confirmed up to and including the abortion procedure (Taylor, 1997:34).

Post-abortion is the period commencing after the abortion procedure (Taylor, 1997:34). The time factor is unlimited.

Crisis is an emotional state of psychological disturbance to the extent that the person feels incapable of dealing with it (Van der Berg, 1997:71).

Crisis intervention is a "process by which the counsellor assesses with the individual in crisis and intervenes in order to restore balance and reduce the consequences of the crisis in her life" (Evangelisti, 2000:44).

\section{CRISIS INTERVENTION AS A MODEL FOR PRE-ABORTION COUNSELLING}

\section{Nature and essence of crisis intervention}

Crisis intervention is regarded as the appropriate model for pre-abortion counselling, because it presents the opportunity for change to those who experience psychological imbalance, feel overwhelmed by their crisis, experience that their inner power is depleted, and endure personal discomfort and unhappiness (Evangelisti, 2000:36,44,45; Van der Berg, 1997:78).

\section{Steps in crisis intervention}

Step 1: Report phase: The first interview must take place as soon as possible after the problem has been reported (Botha, 1995:192). Most decisions with regard to an unwanted pregnancy are made during the first 72 hours after confirmation of the pregnancy. Therefore assistance must be available and accessible immediately after confirmation of the pregnancy. The pregnant woman must be able to experience concern and empathy from the counsellor in that the counsellor demonstrates that she genuinely cares, does not judge the woman and is prepared to listen (Botha, 1995:192; Evangelisti, 2000:45,49; Van der Berg, 1997:81).

Step 2: Decreasing anxiety: The crisis remains the focus point, namely the unwanted pregnancy; the pregnant woman's current level of functioning must be determined in order to analyse her most important problems for the present (Botha, 1995:193). At this stage counselling contributes to the fact that the pregnant woman increasingly develops selfawareness in the relationship, becomes more responsible with regard to contraception and acquires coping skills (McCulloch, 1996:14). 
Step 3: Focus on the crisis, namely the unwanted pregnancy: Feelings and information relevant to the unwanted pregnancy must be worked through with the pregnant woman with a view to diagnosis. A contract must be entered into that covers cooperation concerning a longterm aim, which tasks must receive attention and the therapeutic intervention that must commence immediately (Botha, 1995:192).

Step 4: Evaluation phase: The person who is experiencing a crisis is more open about her feelings and displays hope and trust (Van der Berg, 1997:78). The role of the biological father, and in the case of pregnant minors, the parents' cognisance of the matter must receive attention (Evangelisti, 2000:51,52). The social worker "must help the girl weigh the various alternatives, resolve the abortion crisis to her satisfaction, and view the experience as one episode in her growth toward adulthood" (Cain, 1979:52).

Step 5: Encouraging and supportive action: Evangelisti (2000:52) and Van der Berg (1997:78) agree that the pregnant woman must be encouraged to actively take part in a plan of action with concrete aims during this phase. The counsellor must guard against allowing the pregnant woman to make a rash decision. Following a decision, the counsellor must assist the pregnant woman with appropriate arrangements and give corresponding emotional support (Le Roux \& Botha, 1997:182).

Step 6: Follow-up/closure phase: The pregnant woman's circumstances need to be evaluated and social work services must be terminated (Evangelisti, 2000:53). The moment the person's equilibrium is restored and she sees her situation in perspective, can make decisions independently and is capable of continuing daily life, crisis intervention can be terminated (Botha, 1995:194).

\section{PRE-ABORTION COUNSELLING AND RESEARCH FINDINGS}

\section{Nature and essence of pre-abortion counselling}

Pre-abortion counselling is social work assistance to women who experience a crisis with unwanted pregnancies, with the focus on the crisis, the evaluation of the condition and a plan of action (Forrest, 1994:40). Mogano (1999:22) sees pre-abortion counselling as a process through which the woman is given the opportunity to speak to someone who is sympathetic, emotionally neutral and well informed (Botha, 1995:196). Counselling must be conducted sensitively in order to help the woman to be able to understand and work through the initial shock and denial stage realistically (Taylor, 1997:28,36). Counselling consists of two elements, namely developing a trusting relationship, on the one hand, and giving information with a view to making a responsible decision, on the other (Dondashe, 2001:3).

\section{Purpose of pre-abortion counselling}

Pre-abortion counselling aims at helping women to adapt to a negative life experience, namely an unwanted pregnancy (Evangelisti, 2000:3). Le Roux (1995:186) and Taylor (1997:28) are of the opinion that pre-abortion counselling ensures that the pregnant woman who has requested abortion is given the full opportunity to do an assessment of her uncertainties, wishes and circumstances so as to obtain information and come to know about the available after-care resources and contraceptive methods to prevent yet another unwanted pregnancy in the future (Mogano, 1999:22). Through pre-abortion counselling the pregnant woman can distinguish between her own wishes and those of significant people in her life, so that she can take full responsibility for her own decision (Hildebrand, 1977:9). Howes and Green (1997:18) view the aim of pre-abortion counselling with the pregnant adolescent as providing the opportunity to 
talk about her problems and feelings and to consider the alternatives in order to prevent a rash decision.

\section{The value of pre-abortion counselling}

To illustrate the value of pre-abortion counselling, aspects of the existing pre-abortion programme are contained in the questionnaire; the findings were as follows:

\section{Confirmation of pregnancy}

Confirmation of the pregnancy and establishing the development stage of pregnancy by means of sonar is the first action during pre-abortion counselling (Taylor, 1997:35). On the basis of this, the available time-slot for pre-abortion counselling is fixed. Pregnancy forces the woman to be confronted with her own sexuality, and the discussion of the reasons for the pregnancy and the exploration of her contribution to it leads to her taking responsibility for her deeds (Cain, 1979:54). Many pregnant teenagers pretend that they are not aware of how they had fallen pregnant and rationalise on the actual events. The counsellor can be of help to her in acknowledging and verbalising her feelings (Cain, 1979:55; Le Roux, 1995:188).

TABLE 1

NUMBER OF DAYS AWARE OF THE PREGNANCY

\begin{tabular}{|c|c|c|c|c|c|c|c|c|}
\hline Days aware & 1 day & 2 days & 3 days & 4 days & 5 days & 6 days & 7 days + & Total \\
\hline$=150$ & 3 & 7 & 7 & 6 & 13 & 6 & 108 & 150 \\
\hline $100 \%$ & 2 & 4,67 & 4,67 & 4 & 8,67 & 4 & 72 & $100 \%$ \\
\hline
\end{tabular}

Arising from the current investigations, a frequency table (Table 1) was compiled and it was found that, on presentation, most women - $108(72 \%)$ - had already been aware of the pregnancy for seven days or more. It was not possible to determine the number of days that had elapsed since the woman had suspected that she was pregnant up until it could be confirmed.

TABLE 2

GESTATION PERIOD

\begin{tabular}{|c|c|c|c|c|c|c|c|c|}
\hline Gestation period & 6 weeks & 7 weeks & 8 weeks & 9 weeks & 10 weeks & 11 weeks & 12 weeks & Total \\
\hline $\begin{array}{c}\mathrm{N}=150 \\
\text { Shortfall = 24 }\end{array}$ & 17 & 13 & 24 & 20 & 19 & 18 & 15 & 150 \\
\hline $100 \%$ & 13,49 & 10,32 & 19,05 & 15,87 & 15,08 & 14,29 & 11,90 & $100 \%$ \\
\hline
\end{tabular}

Table 2 indicates that the majority of women who requested an abortion were pregnant between 8 and 11 weeks at conclusion of pre-abortion counselling, namely 8 weeks $-24(19,05 \%), 9$ weeks - $20(15,87 \%)$ and 11 weeks - $18(14,29 \%)$ and 12 weeks - $15(11,90 \%)$ (women had then already reached the gestation period of 12 weeks).

\section{The utilisation of contraception}

According to McCulloch (1996:85) as well as Le Roux and Botha (1997:179), guidance with regard to contraception must be provided in pre-abortion counselling. However, the proper moment for discussing contraception must be chosen sensitively, accurate information must be given on it and the woman must be encouraged to use it (Le Roux \& Botha, 1997:181). The counsellor must guard against confronting the pregnant woman who seriously used contraception and nevertheless fell pregnant. Some women rationalise their use of 
contraception and in so doing shirk their responsibility (Hildebrand, 1977:11). It must be taken into consideration that the woman does not plan every sexual intercourse - it has very much to do with passion (Taylor, 1997:33,45). During this investigation it was found that:

- seventy-nine (79) $(52,67 \%)$ respondents occasionally use some form of contraception or another, while $71(47,33 \%)$ used no form of contraception during confirmation of the unwanted pregnancy;

- having completed the pre-abortion counselling, $121(97,58 \%)$ respondents indicated that they intended seriously using contraception, while only $3(2,42 \%)$ were still indifferent to it. Twenty-six respondents refrained from answering this question;

- therefore $42(44,91 \%)$ respondents had developed an insight into the importance of using contraceptives responsibly with a view to avoiding yet another unwanted pregnancy.

Table 3 gives an exposition of respondents' use of specific contraceptives. Because one specific participant used more than one contraceptive, the following percentages do not add up to $100 \%$.

TABLE 3

THE UTILISATION OF CONTRACEPTIVES

\begin{tabular}{|l|c|c|}
\hline METHOD & $\begin{array}{c}\text { Method used, but will no } \\
\text { longer use it }\end{array}$ & $\begin{array}{c}\text { Method that will be used in } \\
\text { future }\end{array}$ \\
\hline Condom & $29,51 \%$ & $1,64 \%$ \\
\hline The Pill & $15 \%$ & $25 \%$ \\
\hline Depo Provera & $1,67 \%$ & $18,33 \%$ \\
\hline Diaphragm & - & $1,67 \%$ \\
\hline IUCD & $1,67 \%$ & $3,33 \%$ \\
\hline Sterilisation & - & $8,33 \%$ \\
\hline Other methods & $1,67 \%$ & $5 \%$ \\
\hline
\end{tabular}

There is a decrease $(27,87 \%)$ in respondents who initially used condoms and no longer consider it a dependable contraceptive, while there is an increase (10\%) in those who consider using the pill as a contraceptive. With the initial test it was determined that no respondents had used sterilisation, but in the post-test $8,33 \%$ respondents considered using this permanent contraceptive.

\section{Informing other significant people}

The pregnant woman must be encouraged to confide in someone in order to support her during the decision-making process. Companionship and support can ease the tension experienced by the woman who finds herself in a crisis, and gives her the opportunity to strengthen her coping ability (Botha, 1995:198). Many women are never given the opportunity to be guided through this crisis by means of pre-abortion counselling (Le Roux \& Botha, 1997:179; Taylor, 1997:43,79). The teenage girl has the right to decide whether or not to inform her parents of the termination of the pregnancy. The counsellor can act as a go-between if the teenage girl fears her parents' reaction and can prepare her for possible reactions of her parents (Le Roux \& Botha, 1997:180; Mkhize, 2000:95; Taylor, 1997:43). Some teenagers are determined on undergoing the abortion procedure all on their own. The pregnant teenager must realize that secrecy can unleash destructive emotions (Sekudu, 2001:96). 
TABLE 4

INFORMING SOMEONE ABOUT THE PREGNANCY AND/OR

REQUEST FOR AN ABORTION

\begin{tabular}{|l|c|c|}
\hline A. DID NOT INFORM SOMEONE & $\begin{array}{l}\text { Number }=150 \\
\text { Shortfall }=12\end{array}$ & $100 \%$ \\
\hline Informed someone about it later & 2 & 1,45 \\
\hline $\begin{array}{l}\text { Is sick at heart and depressed to have to bear this crisis and } \\
\text { assimilate it all on her own }\end{array}$ & 3 & 2,17 \\
\hline Is resigned to keep it a secret & 13 & 9,42 \\
\hline Did not go ahead with the procedure & 2 & 1,45 \\
\hline Left this question unanswered in second questionnaire & 2 & 1,45 \\
\hline SUB-TOTAL & 22 & 15,94 \\
\hline B. INFORMED SOMEONE and REASONS FOR DOING SO & 46 & 33,33 \\
\hline Unwilling to or incapable of handling the crisis all on her own & 43 & 31,16 \\
\hline Need for understanding and support & 27 & 19,57 \\
\hline Need for assistance, advice and guidance & 116 & 84,06 \\
\hline SUB-TOTAL & 138 & 100 \\
\hline TOTAL &
\end{tabular}

In the current investigation $22(15,94 \%)$ respondents informed no one about the unwanted pregnancy or request for an abortion, while $116(84,06 \%)$ respondents indeed did so. Twelve respondents refrained from answering this question. Table 4(A) gives an indication of the details pertaining to respondents who informed no one and how they felt about it. Opposed to this, the details pertaining to those who did indeed so and their reasons for doing so appear in the second.

\section{Religion and moral aspects}

It is general knowledge that women who have undergone an abortion are preoccupied with the notion of punishment and then ascribe everything that goes wrong later in their lives to the abortion - feelings of guilt, anger, inability to establish and maintain relationships, increasing promiscuity, repeated pregnancies and abortions. The counsellor must identify her spiritual needs and refer her appropriately. Occasionally women apply defence mechanisms to survive emotionally (Taylor, 1997:44). The personal judgements of the woman who requests an abortion need to be worked through with her and she must be guided to forgive herself (Sekudu, 2001:196).

This investigation found that:

- ninety (90) (75\%) respondents' opinions on abortion remained unchanged - of which 42 $(46,67 \%)$ saw it as right and $48(53,33 \%)$ as wrong;

- sixteen (16) $(13,33 \%)$ respondents who initially regarded abortion to be wrong regarded it to be right in the post-test;

- fourteen $(14)(11,67 \%)$ respondents who initially saw abortion as right, saw it as wrong in the post-test;

- thirty (30) of the 150 respondents refrained from answering these questions. 


\section{Motives for abortion and social circumstances}

As the level of anxiety of a woman who requests an abortion decreases, clarification of the situation becomes increasingly necessary. She develops insight into her circumstances and comes to grips with the crisis (Botha, 1995:198). In accordance with this, 49 (40,50\%) of 121 respondents' initial and later motives with regard to abortion changed during this investigation, while $72(59,50 \%)$ respondents' motives remained unchanged throughout. Twenty-nine respondents refrained from answering this question. The following table gives a few examples.

\section{TABLE 5}

\section{MOTIVES FOR TERMINATING PREGNANCY}

\begin{tabular}{|c|c|c|}
\hline NO & $\begin{array}{l}\text { Questionnaire at commencement of } \\
\text { pre-abortion counselling }\end{array}$ & $\begin{array}{l}\text { Questionnaire at conclusion of pre- } \\
\text { abortion counselling }\end{array}$ \\
\hline 3 & $\begin{array}{l}\text { "I think abortion will solve my } \\
\text { problem." }\end{array}$ & $\begin{array}{l}\text { "Because right now, I don't want the baby, } \\
\text { and things are complicated. I don't know } \\
\text { who the father of this child is." }\end{array}$ \\
\hline 34 & $\begin{array}{l}\text { "I don't want a baby. My youngest is } \\
\text { premature and unhealthy. According my } \\
\text { in-laws I must raise up my children } \\
\text { first." }\end{array}$ & $\begin{array}{l}\text { "I have two children. The biological father } \\
\text { doesn't want another child." }\end{array}$ \\
\hline 84 & $\begin{array}{l}\text { "I don't want a baby. I will not } \\
\text { disappoint my parents." }\end{array}$ & "Keep the baby." \\
\hline 108 & $\begin{array}{l}\text { "It is the best option now. I'm busy with } \\
\text { studies, I'm not married and financially I } \\
\text { can't afford to keep the baby". }\end{array}$ & $\begin{array}{l}\text { "Because I'm emotional and financially not } \\
\text { prepared for a baby." }\end{array}$ \\
\hline
\end{tabular}

With regard to the $72(59,50 \%)$ respondents whose motives remained unchanged throughout, the reasons are categorised and displayed in Table 6 below.

TABLE 6

REASONS FOR TERMINATING PREGNANCY

\begin{tabular}{|l|c|c|}
\hline \multicolumn{1}{|c|}{ Categories of reasons } & $\begin{array}{c}\text { Total } \mathbf{N}=\mathbf{1 5 0} \text { Shortfall = 29 } \\
\text { Different reasons = 49 }\end{array}$ & $\mathbf{1 0 0 \%}$ \\
\hline Finances & 10 & 13,89 \\
\hline Already have children & 10 & 13,89 \\
\hline Do not wish to disappoint parents & 6 & 8,33 \\
\hline Study & 10 & 13,89 \\
\hline Not ready for a child/another child & 18 & 25,00 \\
\hline Biological father & 12 & 16,67 \\
\hline Other reasons & 6 & 8,33 \\
\hline TOTAL & 72 & $100 \%$ \\
\hline
\end{tabular}

Most respondents, namely 18 (25\%), indicated that they were not ready for a child or another child, while finances and the fact that the pregnant woman already has children, or that they were still at school or studying, were each given as reasons by $10(13,89 \%)$. Not disappointing parents as a reason for their request for an abortion was stated by $6(8,33 \%)$ respondents. These 


\section{6}

findings confirm that most pregnant women do not think of the consequences of a possible pregnancy beforehand. It only becomes a reality once the pregnancy has been confirmed.

This investigation attempted to determine the relationship between the respondents' initial and later justification of their social circumstances as reason for abortion:

- Thirteen (13) $(10,66 \%)$ respondents initially indicated that their circumstances justify an abortion, but indicated the opposite in the post-test;

- Twelve (12) $(9,84 \%)$ respondents initially indicated that their circumstances did not justify an abortion, but in the post-test they indicated that it did indeed justify abortion;

- Eighty-seven (87) (71,31\%) respondents indicated that their circumstances justified an abortion during both the pre- and post-test;

- Ten $(10)(8,2 \%)$ respondents indicated that their circumstances did not justify an abortion during both the pre- and post-test;

- Twenty-eight (28) (18,6\%) of the 150 respondents refrained from answering this question.

\section{The concept of abortion}

The pregnant woman who requests abortion must develop an insight into the meaning of an abortion during the abortion counselling and she must be able to distinguish it from miscarriage and therapeutic abortion (Sekudu, 2001:39). Backstreet abortion and its complications must be explained, because such practices are still common (Taylor, 1997:39).

- In this investigation, $101(84,17 \%)$ respondents' initial understanding of the concept abortion remained unchanged.

- Nineteen (19) (15,83\%) respondents developed an insight into what an abortion entails and a couple of examples are indicated in Table 7.

- Thirty (30) of the 150 respondents did not answer this question meaningfully.

TABLE 7

DEFINITION OF ABORTION

\begin{tabular}{|c|l|l|}
\hline No & \multicolumn{1}{|c|}{$\begin{array}{c}\text { Definition at commencement of } \\
\text { counselling }\end{array}$} & Definition at conclusion of counselling \\
\hline 2 & $\begin{array}{l}\text { Less knowledge about abortion. If you } \\
\text { didn't want the baby, you can have an } \\
\text { abortion. }\end{array}$ & $\begin{array}{l}\text { You have a choice to be pregnant }- \text { to } \\
\text { have a child or not. }\end{array}$ \\
\hline 9 & Don't know. & Removal of the foetus. \\
\hline 21 & The pills will let the baby come out. & To destroy the pregnancy. \\
\hline 34 & Take out of dirty blood. & Removal of the unborn baby. \\
\hline 80 & If you don't want a child. & To kill a foetus. \\
\hline
\end{tabular}

The relationship between sex and pregnancy was subsequently investigated and it was found that:

- ninety-eight (98) $(79,67 \%)$ respondents maintained the view that there is a link between sex and pregnancy, while $16(13,01 \%)$ initially indicated that there is a relationship, but changed their mind in the meantime in the post-test; 
- eight (8) $(6,51 \%)$ respondents initially indicated that there is no link between sex and pregnancy, but changed their minds in the meantime in the post-test;

- only $1(0,81 \%)$ participant indicated in the pre- and post-test that there is no link between sex and pregnancy;

- twenty-seven (27) of the 150 respondents refrained from answering these questions.

\section{Development stages of the foetus}

The pregnant woman who considers an abortion must have knowledge of foetal development prior to deciding on an abortion (McCulloch, 1996:68). This aspect was investigated and the relationship was determined between the initial and later opinions as to whether or not the foetus is a living being.

- Seventy-nine (79) (64,23\%) respondents' opinions remained unchanged, namely 60 $(48,78 \%)$ were convinced that the foetus is a living being, while $19(15,45 \%)$ indicated the opposite.

- Forty-four (44) $(35,77 \%)$ respondents' opinions changed, of which $42(34,15 \%)$ previously did not see a foetus as a living being and following pre-abortion counselling saw it as a living being, and $2(1,63 \%)$ respondents who initially believed that the foetus is a living being later changed their opinion.

- Twenty-seven (27) of the 150 respondents refrained from answering the question.

\section{Abortion procedure}

The pregnant woman who requests an abortion must be informed in an acceptable but honest manner about the different methods of abortion (Cain, 1979:40; Sekudu, 2001:41,43; Van der Berg, 1997:18,19). She must also be prepared for the specific abortion procedure as well as the myths and misrepresentations about them, seeing that they can cause anxiety and impede recovery (De Vynck, 1999:20; Taylor, 1997:36). During an investigation women indicated that they wished to obtain more information on abortion procedures and potential risks (McCulloch, 1996:68). Pregnant women who request an abortion are often uninformed about the time aspect involved in an abortion, and they should be prepared for possible physical pain, discomfort and bleeding, which form part of the procedure (McCulloch, 1996:68). This recommendation corresponds with findings of this investigation, as set out in Table 8.

TABLE 8

EXPECTATIONS WITH REGARD TO PRE-ABORTION COUNSELLING

\begin{tabular}{|l|c|c|}
\hline \multicolumn{1}{|c|}{ Expectations } & $\begin{array}{c}\mathbf{N = 1 5 0} \\
\text { Shortfall = 12 }\end{array}$ & $\mathbf{1 0 0 \%}$ \\
\hline Abortion procedures and relevant information & 90 & 65,22 \\
\hline Effects of abortion & 24 & 17,4 \\
\hline Decision-making & 8 & 5,8 \\
\hline Coping with feelings and emotions & 5 & 3,62 \\
\hline Uncertainty or no expectations & 11 & 7,97 \\
\hline TOTAL & 138 & 100 \\
\hline
\end{tabular}

The majority of the respondents, namely $90(65,22 \%)$, had the expectation that relevant information on the abortion procedure will be given to them during pre-abortion counselling, and $24(17,4 \%)$ expected information on the effects of an abortion. Eleven $(7,97 \%)$ respondents 
were uncertain or had no significant expectations with regard to pre-abortion counselling, and 8 $(5,8 \%)$ had expectations regarding assistance with decision-making. Five $(3,62 \%)$ expected counselling on coping with feelings and emotions. From these findings it can be seen that most participants in the study had a realistic view of what can be expected during pre-abortion counselling.

\section{Alternatives to abortion}

A two-way table (Table 9) was compiled to determine the relationship between options, on the one hand, and abortion as only choice, on the other.

\section{TABLE 9}

\section{RELATIONSHIP BETWEEN OPTIONS AND ABORTION AS THE ONLY CHOICE}

\begin{tabular}{|l|c|c|c|}
\hline \multicolumn{1}{|c|}{ OPTIONS } & \multicolumn{2}{|c|}{ ABORTION AS ONLY CHOICE } & TOTAL \\
\hline & Yes, only abortion & No, not only choice & \\
\hline Alternative options & 7 & 17 & 24 \\
&, $74 \%$ & $13,93 \%$ & $19,67 \%$ \\
\hline No alternative options & 75 & 23 & 98 \\
& $61,48 \%$ & $18,85 \%$ & $80,33 \%$ \\
\hline TOTAL = 150 Shortfall = 28 & 82 & 40 & 122 \\
$100 \%$ & $67,21 \%$ & $32,79 \%$ & $100 \%$ \\
\hline
\end{tabular}

Thirty $(24,59 \%)$ respondents' opinions on options remained unchanged before and after preabortion counselling, seven $(5,74 \%)$ indicated that there were other options besides abortion and $23(18,85 \%)$ indicated that there are no other options besides abortion. Ninety-two $(75,41 \%)$ respondents changed their opinion regarding options by the time the post-test was written $-75(61,48 \%)$ regarded abortion as the only option by then, while $17(13,93 \%)$ were of opinion that there are indeed also other options besides abortion.

McCulloch (1996:14) refers to alternatives as psychological variables and the pregnant woman needs to be helped in a non-judgmental and neutral manner to make an informed and coherent decision. The woman with an unwanted pregnancy must be enabled to use her negative experience as a growth process by making a responsible decision (Le Roux, 1995:188).

- Single-parenthood: The woman's natural reaction is to keep the baby, but she must be helped to envisage the future and to provide for the future as far as possible. Her support system also needs to be exploited and developed (Van der Berg, 1997:39). The pregnant woman must be given the opportunity to decide on her own situation with regard to single parenthood (Evangelisti, 2000:56; Van der Berg, 1997:39).

- Matrimony: The biblical model of marriage is the ideal for creating a stable family life (Schlossberg \& Achtemeier, 1995:112). However, the pregnancy does not necessarily have to force the mother and biological father to marry, because matrimony is not always the best solution (Evangelisti, 2000:55; Van der Berg, 1997:40).

- Adoption: Adoption is coupled with the emotional pain of loss, but it presents a life-saving alternative. It is a legitimate way of giving a stable home to a child who is born in a crisis (Schlossberg \& Achtemeier, 1995:112). In accordance with the Amendment Act on Adoption Matters, 1998 (Act 56 of 1998), the biological father's rights may not be blatantly ignored (Louw, 2004:102; SA, 1998:3). 
- Foster care: Foster care is substitute care within a family context (kinship care) or care by approved foster parents for children who cannot be cared for or educated by their biological parents. This is a legal procedure and cannot really be regarded as an option in pregnancy decision-making unless a social work investigation reveals that the child is in need of care (Evangelisti, 2000:58; SA, 1983:208).

TABLE 10

ALTERNATIVES TO ABORTION

\begin{tabular}{|c|c|c|c|c|c|c|}
\hline Alternatives & $1^{\text {st }}$ choice & 2nd choice & 3rd choice & $4^{\text {th }}$ choice & TOTAL & \\
\hline \multicolumn{7}{|c|}{ OPINION AT COMMENCEMENT OF PRE-ABORTION COUNSELLING } \\
\hline Abortion & $115(95,83 \%)$ & & & $\begin{array}{c}5 \\
(4,17 \%)\end{array}$ & \multirow{4}{*}{$\begin{array}{c}120 \\
100 \% \\
58 \\
100 \% \\
58 \\
100 \% \\
63 \\
100 \%\end{array}$} & Shortfall $=30$ \\
\hline Adoption & & $\begin{array}{c}18 \\
(31,03 \%)\end{array}$ & $\begin{array}{c}15 \\
(25,9 \%)\end{array}$ & $25(43,10 \%)$ & & Shortfall $=92$ \\
\hline Foster care & & $\begin{array}{c}8 \\
(13,79 \%) \\
\end{array}$ & $\begin{array}{c}39 \\
(67,24 \%) \\
\end{array}$ & $\begin{array}{c}11 \\
(18,97) \\
\end{array}$ & & Shortfall $=92$ \\
\hline $\begin{array}{l}\text { Single } \\
\text { parent }\end{array}$ & $\begin{array}{c}9 \\
(14,29 \%)\end{array}$ & $\begin{array}{c}33 \\
(52,38 \%)\end{array}$ & $\begin{array}{c}4 \\
(6,35 \%)\end{array}$ & $\begin{array}{c}17 \\
(26,98 \%)\end{array}$ & & Shortfall $=87$ \\
\hline \multicolumn{7}{|c|}{ OPINION AT CONCLUSION OF PRE-ABORTION COUNSELLING } \\
\hline Abortion & $\begin{array}{c}97 \\
(91,51 \%)\end{array}$ & $\begin{array}{c}2 \\
(1,89 \%)\end{array}$ & $\begin{array}{c}1 \\
(0,94 \%)\end{array}$ & $\begin{array}{c}6 \\
(5,66 \%) \\
\end{array}$ & \multirow{4}{*}{$\begin{array}{c}106 \\
100 \% \\
59 \\
100 \% \\
64 \\
100 \% \\
60 \\
100 \%\end{array}$} & Shortfall $=44$ \\
\hline Adoption & & $\begin{array}{c}19 \\
(32,20 \%)\end{array}$ & $\begin{array}{c}17 \\
(28,81) \\
\end{array}$ & $\begin{array}{c}23 \\
(39) \\
\end{array}$ & & Shortfall = 91 \\
\hline Foster care & $\begin{array}{c}1 \\
(1,7 \%) \\
\end{array}$ & $\begin{array}{c}11 \\
(18,64 \%) \\
\end{array}$ & $\begin{array}{c}34 \\
(57,63 \%) \\
\end{array}$ & $\begin{array}{c}18 \\
(22,03 \%) \\
\end{array}$ & & Shortfall $=86$ \\
\hline $\begin{array}{l}\text { Single } \\
\text { parent }\end{array}$ & $\begin{array}{c}11 \\
(18,33 \%)\end{array}$ & $\begin{array}{c}26 \\
(43,33 \%)\end{array}$ & $\begin{array}{c}6 \\
(10 \%)\end{array}$ & $\begin{array}{c}17 \\
(28,33 \%)\end{array}$ & & Shortfall $=90$ \\
\hline
\end{tabular}

Table 10 indicates that, during this investigation, respondents placed the alternatives at both commencement and conclusion of pre-abortion counselling in the same order of preference, namely:

\begin{tabular}{|ll|l|l|}
\hline & PRE-TEST & POST-TEST \\
\hline First choice: & Abortion & $115(95,83 \%$ & $97(91,51 \%)$ \\
\hline Second choice: & Single parent & $33(52,38 \%)$ & $26(43,33 \%)$ \\
\hline Third choice: $\quad$ Adoption & $18(31,03 \%)$ & $19(32,20 \%)$ \\
\hline Fourth choice: $\quad$ Foster care & $39(67,24 \%)$ & $34(57,63 \%)$ \\
\hline
\end{tabular}

From this it is clear that pre-abortion counselling did not necessarily make the respondents change their minds, but indeed enabled them to make an informed and well-considered decision after having considered all possible options. 


\section{After-effects of abortion}

\section{Physical effects}

Most women have abortions done secretly and the absence of assistance and significant others in the world the woman lives in is reflected in her condition. The most general complications are infection, menstrual deviations, secondary infertility, spontaneous abortions in the future and premature births. Other risk factors are the age of the pregnant woman who requests an abortion, the method of abortion and the skill of the person who performs the abortion (Sekudu, 2001:47).

\section{Emotional effects}

By preparing the woman for the different feelings that she might experience, she is given approval to experience such feelings rather than to suppress them (Le Roux \& Botha, 1997:175; Taylor, 1997:36). External behaviour reflects inner feelings and the counsellor must observe this intuitively. The counsellor must manage emotional pain by means of reflection, questioning and individualisation. By doing this, the pregnant woman experiences that she is treated decently and that the counsellor cares for her as a person. During intense trauma, when words are meaningless, physical contact is a valuable method of communicating (Botha, 1995:197-198). The patient must be prepared for the immediate feeling of relief following the procedure, but that this is succeeded by feelings of wanting to cry as an expression of the feeling of loss that she experiences (Taylor, 1997:25). The pregnant woman also has to focus on broader implications, while she must cope with the loss of her pregnancy. Even though she has made the choice to undergo an abortion, she is still grieving over the loss of the baby. The loss of the foetus is not insignificant and it has a long-term effect on the woman. Pre-abortion counselling is therefore important to ease the process of assimilation and to shorten the grieving process (De Vynck, 1999:44; Le Roux, 1995:186; Sekudu, 2001:97).

\section{The meaningfulness of pre-abortion counselling}

During the investigation that was conducted in Potchefstroom Hospital, it was found that the respondents considered pre-abortion counselling to be important:

- The opinion of $99(81,15 \%)$ respondents remained unchanged, namely $95(77,87 \%)$ who initially were positive towards pre-abortion counselling maintained their opinion, and 4 $(3,28 \%)$ who initially were negative;

- Twenty-one (21) $(17,21 \%)$ respondents who did not regard pre-abortion counselling to be important previously, saw it as important after their pre-abortion counselling;

- Two (2) $(1,64 \%)$ respondents who saw pre-abortion counselling as important initially displayed a negative attitude towards it in the post-test;

- Twenty-eight (28) of the 150 respondents refrained from answering this question.

The counsellor is one of the first people the pregnant woman speaks to about her crisis. Some women have already decided on an abortion, but do benefit from counselling in that they acquire knowledge about alternatives that are available and any resources that they can utilise. Individual counselling is beneficial in that the woman's values, self-interest and available support are reflected on, so that a well-considered instead of an impulsive decision is made (Mogano, 1999:23). Naidoo and Moodley (2002:29) stress the importance of the period of one week starting from the request and counselling until the abortion procedure takes place. According to the findings of the investigation that was undertaken in Potchefstroom Hospital, $116(92,80 \%)$ respondents were capable of making an informed decision after three pre- 
abortion counselling sessions, while $3(2,40 \%)$ held the opinion that they were not capable of doing so, and $6(4,8 \%)$ were uncertain. Twenty-five (25) of the 150 respondents refrained from answering this question.

The pregnant woman who requests an abortion has the right and the responsibility to claim service of a high quality during this crisis, says Kaufman (1997:1). She is entitled to emotional support and adequate medical treatment that is sensitive to her needs. During the investigation, a survey was done on why respondents see pre-abortion counselling as important; the findings are set out in Table 11.

TABLE 11

IMPORTANCE OF PRE-ABORTION COUNSELLING

\begin{tabular}{|l|l|c|c|}
\hline \multicolumn{1}{|c|}{$\begin{array}{c}\text { RRDER OF } \\
\text { PREFERENCE }\end{array}$} & \multicolumn{1}{|c|}{$\begin{array}{c}\text { TOTAL = 150 } \\
\text { Shortfall = 9 }\end{array}$} & \% \\
\hline 1. & $\begin{array}{l}\text { To get information and broaden } \\
\text { knowledge. }\end{array}$ & 68 & $48,23 \%$ \\
\hline 2. & Get clarity on decision-making. & 15 & $10,64 \%$ \\
\hline 3. & To discuss alternatives/options. & 21 & $9,99 \%$ \\
\hline 4. & $\begin{array}{l}\text { To be better prepared to be able to cope } \\
\text { with a crisis. }\end{array}$ & 14 & $13,48 \%$ \\
\hline 5. & Support and understanding & 4 & $2,84 \%$ \\
\hline 6. & Counselling is not seen to be important. & $\mathbf{1 4 1}$ & $\mathbf{1 0 0 \%}$ \\
\hline TOTAL & &
\end{tabular}

It was found that the respondents mainly regarded pre-abortion counselling to be important in that $68(48,23 \%)$ respondents wished to gain specific information and $15(10,64 \%)$ respondents wished to get clarity on decision-making. According to $14(9,99 \%)$ respondents, the importance of pre-abortion counselling lies in the fact that alternatives are discussed, for $21(14,89 \%)$ respondents it lies in the preparation for coping with the crisis, and according to $19(13,48 \%)$ respondents, it lies in the support and understanding they experienced. There were even four respondents $(2,84 \%)$ who did not see pre-abortion counselling as important. A few examples of those who initially regarded pre-abortion counselling to be unimportant, but nevertheless benefited from it, appear in the table below.

TABLE 12

OPINION ON PRE-ABORTION COUNSELLING

\begin{tabular}{|l|l|l|}
\hline Participant & \multicolumn{1}{|c|}{ Pre-test } & \multicolumn{1}{c|}{ Post-test } \\
\hline Number 58 & "Not necessary. I've decided." & "Correct information." \\
\hline Number 34 & "Not necessary. I know what I want." & "Physical after effects." \\
\hline
\end{tabular}

Table 13 reflects the relationship between the respondents who benefited from pre-abortion counselling compared to those who did not benefit from it. 
TABLE 13

FEEDBACK ON PRE-ABORTION COUNSELLING

\begin{tabular}{|c|c|c|c|}
\hline RESPONDENTS & TOTAL & RESPONDENTS & TOTAL \\
\hline $\begin{array}{l}\text { Will benefit from it - did } \\
\text { indeed benefit from it }\end{array}$ & $\begin{array}{c}97 \\
80,17 \%\end{array}$ & $\begin{array}{l}\text { Will not benefit from it }- \text { did not } \\
\text { benefit from it }\end{array}$ & $\begin{array}{c}3 \\
2,48 \%\end{array}$ \\
\hline $\begin{array}{l}\text { Will not benefit from it - } \\
\text { did indeed benefit from it }\end{array}$ & $\begin{array}{c}16 \\
13,22 \%\end{array}$ & $\begin{array}{l}\text { Will benefit from it - Did not benefit } \\
\text { from it }\end{array}$ & $\begin{array}{c}5 \\
4.13 \% \\
\end{array}$ \\
\hline $\begin{array}{l}\text { BENEFITED FROM } \\
\text { PRE-ABORTION } \\
\text { COUNSELLING }\end{array}$ & $\begin{array}{c}113 \\
93,39 \%\end{array}$ & $\begin{array}{l}\text { DID NOT BENEFIT FROM PRE- } \\
\text { ABORTION COUNSELLING }\end{array}$ & $\begin{array}{c}8 \\
6,61 \%\end{array}$ \\
\hline \multicolumn{4}{|c|}{$\begin{array}{l}\text { TOTAL = } 150(\text { Shortfall = 29) } \\
100 \%\end{array}$} \\
\hline
\end{tabular}

The relationship between the expectations of the respondents with regard to pre-abortion counselling and feed-back on pre-abortion counselling was determined, and it is clear that the majority $113(93,39 \%)$ did indeed benefit from it and that $8(6,61 \%)$ did not benefit from it.

With regard to being emotionally prepared for the abortion procedure after pre-abortion counselling, the investigation found as follows:

\begin{tabular}{|l|l|}
\hline $86,4 \%$ & emotionally prepared \\
\hline $5,6 \%$ & emotionally not prepared for the abortion procedure \\
\hline $8,0 \%$ & Uncertain whether they were emotionally prepared \\
\hline
\end{tabular}

\section{SUMMARY}

The literature and research findings can be aligned regarding the importance of pre-abortion counselling for the pregnant woman who requests termination of pregnancy. The pregnant woman who requests an abortion is dependent on social work assistance, specifically in the form of pre-abortion counselling. The nature and essence of pre-abortion counselling corresponds with that of crisis intervention, and therefore crisis intervention is regarded as the obvious model for pre-abortion counselling. The different steps during crisis intervention taken into consideration, the process of pre-abortion counselling with its contextual aspects can be implemented successfully in the interests of the pregnant woman who finds herself in a crisis. If the importance of pre-abortion counselling is stressed and marketed better, and every pregnant woman who requests an abortion can realise its value, then an actual contribution can be made towards preventing impulsive decision-making and adopting the wrong approach to treating this crisis in her life. Therefore the importance of pre-abortion counselling cannot be overemphasised. Clearly, the social worker has an important task to fulfil in this respect.

\section{REFERENCES}

BABBIE, E. 2004. The practice of social research. New York: Wadsworth/ Thompson.

BLOOM, M., FISCHER, J. \& ORME, J.G. 1999. Evaluating practice: guidelines for the accountable professional. Englewood Cliffs: Prentice Hall.

BOTHA, H.S. 1995. Social work services to newly arrested juveniles. Bloemfontein: University of the Free State. (SocSc Dissertation) 
BRITZ, J.J. 1997. Educational psychological support to adolescents that underwent abortions. Johannesburg: Rand Afrikaans University. (MEd Dissertation)

CAIN, L.P. 1979. Social worker's role in teenage abortions. Social Work, 24(1):52.

CRESWELL, J.W. 2003. Research design: qualitative, quantitative and mixed method approaches. New York: Sage Publications.

DE VOS, A.S., STRYDOM, H., FOUCHÉ, C.B. \& DELPORT, C.S.L. 2005. Research at grass roots: for the social sciences and human service professions. Pretoria: Van Schaik Publishers.

DE VYNCK, S. 1999. Counselling to adolescent girls who want to do an termination of pregnancy. Johannesburg: Rand Afrikaans University. (MEd Dissertation)

DONDASHE, V.I. 2001. The experience of registered nurses in the pre-counselling of pregnant women contemplating termination of pregnancy. Port Elizabeth: University of Port Elizabeth. (Mini-treatise - MCur)

EVANGELISTI, L. 2000. Adolescent resolution with special reference to pre-abortion counselling. Stellenbosch: University of Stellenbosch. (MA Thesis)

FORREST, G.M. 1994. Emotional distress in women before and after therapeutic terminations of pregnancy: an investigation into the need for pre- and post-abortion counselling. Cape Town: University of Cape Town. (MSc Dissertation)

GAMEAU, B. 1993. Termination of pregnancy: development of a high-risk screening and counselling program. Social Work in Health Care, 18(3/4):179-191.

HILDEBRAND, J. 1977. Abortion: with particular reference to the developing role of counselling. British Journal of Social Work, 7(1):3-24.

HOWES, F. \& GREEN, S. 1997. Illegitimate motherhood in the Paarl-Wellington area: the caring potential and support system of the teenage mother. Cooperative Research Programme re Marriage and Family Life, Stellenbosch. Pretoria: Human Sciences Research Council.

KAUFMAN, K. 1997. The abortion resource handbook. New York: Simon \& Schuster Inc.

KRETZSCHMAR, L. \& HULLEY, L. 1998. Questions about life and morality. Pretoria: Van Schaik Publishers.

LE ROUX, J.P. 1995. Abortion in South Africa: a social work perspective. Bloemfontein: University of the Free State. (PhD Thesis)

LE ROUX, J.P. \& BOTHA, D. 1997. Abortion counselling by the social worker for pregnant teenagers and older women. The Social Work Practitioner-Researcher, 10(2):169-188.

LOUW, A.S. 2004. Adoption rights of natural fathers T v C 20032 SA 298 (W). Journal of Contemporary Roman-Dutch Law, 67(1):102-114.

McCULLOCH, U.R. 1996. Women's experiences of abortion in South Africa: an exploratory study. Cape Town: University of Cape Town. (MA Dissertation)

MKHIZE, B.A. 2000. The Termination of Pregnancy Act of 1996: a theological ethical evaluation of abortion on demand. Pretoria: University of Pretoria. (MTh Dissertation) 
MOGANO, M.S. 1999. Factors influencing the decision of teenagers to terminate their pregnancies. Johannesburg: Rand Afrikaans University. (MSocSc mini Dissertation)

NAIDOO, T.D. \& MOODLEY, J. 2002. Termination of pregnancy: do women change their decision following counselling? The South African Journal of Epidemiology and Infection, 17(1-2):29-33.

NEUMAN, W.L. 2003. Social research methods: qualitative and quantitative approaches. Boston: Allyn and Bacon.

PARRY, G. 1990. Coping with crises. London: The British Psychological Society and Routledge Ltd. (PBS Books).

ROYSE, D. 2004. Research methods in social work. Toronto: Thomson Brooks/Cole.

RUBIN, A. \& BABBIE, E. 2001. Research methods for social work. Toronto: Wadsworth/ Thompson.

SA see SOUTH AFRICA.

SCHLOSSBERG, T. \& ACHTEMEIER, E. 1995. Not my own. New York: William E Eerdmans Publishing Company.

SEKUDU, J. 2001. Abortion: a social work study. Pretoria: University of Pretoria. (DPhil Thesis)

SOUTH AFRICA. 1983. Children's Act, No 92 of 1974. Pretoria: Government Printer.

SOUTH AFRICA. 1996. Choice on Termination of Pregnancy Act, No 92 of 1996. Pretoria: Government Printer.

SOUTH AFRICA. 1998. Amendment Act on Adoption Matters, No 56 of 1998. Pretoria: Government Printer.

STRYDOM, H. 1999. Social work research. Potchefstroom: PU for CHE.

TAYLOR, G.L. 1997. Women's experience of abortion - a qualitative study. East London: Rhodes University. (MSocSc Thesis)

VAN DER BERG, R. 1997. Called to care: a Christian counselling perspective on abortion. Pretoria: Group 7 Printers \& Publishers.

Prof Herman Strydom, Professor and Head of Social Work, School of Psycho-Social Behavioural Sciences, Potchefstroom Campus, North-West University, South Africa; Dr Susan Humpel, PhD student and Head of the Social Work Department, Potchefstroom Hospital Health Department, North West Province, South Africa. 